\title{
Urinary extract profiles of illegal substances at psychiatry and dependency clinics: three years report
}

\author{
Pelin Tanyeri $^{1}$, Ahmet Bulent Yazici ${ }^{2} *$, Mehmet Emin Buyukokuroglu ${ }^{1}$, \\ Esra Yazici ${ }^{3}$, Atila Erol $^{3}$
}

${ }^{1}$ Department of Pharmacology, Sakarya University, Faculty of Medicine, Sakarya, Turkey ${ }^{2}$ Department of Psychiatry, Sakarya University, Training and Research Hospital, Sakarya, Turkey

${ }^{3}$ Department of Psychiatry, Sakarya University, Faculty of Medicine, Sakarya, Turkey

Received: 04 January 2017 Accepted: 03 February 2017

*Correspondence to:

Dr. Ahmet Bulent Yazici, Email: a.bulentyaz@gmail.com

Copyright: (C) the author(s), publisher and licensee Medip Academy. This is an openaccess article distributed under the terms of the Creative Commons Attribution NonCommercial License, which permits unrestricted noncommercial use, distribution, and reproduction in any medium, provided the original work is properly cited.

\begin{abstract}
Background: Substance abuse is a serious problem all over the world. There are many studies report the illegal substance use profile but few studies present their toxicology laboratory analysis. This study reports a quantitative profile of (Urine Drug Screening)) for illegal substances in Sakarya-Turkey.

Methods: This study presents the urine analysis of all illegal substances which were made in the laboratory of Sakarya Training Research Hospital between March 2012 and February 2015. The results obtained from socio-demographic data and urine tests of patients were analyzed by examining their hospital record files. Urine drug screening was conducted with immunoassay quantitative analysis.

Results: People subjected to substance analysis $(n=2948)$ ages vary between 12 and 76 , their mean age was $28.30 \pm 9.46 .96 .74 \%(n=2852)$ of them were males. Substance positivity was determined in $34.73 \%$ of all patients $(n=1024 / 2948)$ and their ages varied between 14 and 70 and their mean age was 29.39 \pm 9.65 . Distribution of the urine positivity of the substances contained: marijuana 79, $5 \% \quad(n=814)$, amphetamine $30.17 \% \quad(n=309)$, ecstasy $23.74 \% \quad(n=199)$, benzodiazepine $9,1 \%(\mathrm{n}=94)$, synthetic cannabinoid $4.9 \%(\mathrm{n}=12 / 243)$; opioid $5.2 \%(n=54)$, cocaine $1.67 \%(n=14)$ and multiple substance $29.9 \%(n=308)$.

Conclusions: According to this study, marijuana is the most frequently used substance and multiple substance use is common. Synthetic cannabinoid seems to take place rapidly among the users. Updating the kits is important to reach the correct information in drug screening tests.
\end{abstract}

Keywords: Illegal, Probation, Substance, Urine drug screening

\section{INTRODUCTION}

Substance abuse is a serious problem all over the world. In the field of addiction, assessment of psychoactive substance use is a key element for diagnosis and medical management. But, studies about the substance use are mostly used the data obtained self-report of patients. ${ }^{1}$ Nevertheless, this assessment is often difficult as selfreports underestimate the use of psychoactive substances. ${ }^{2-6}$ Urine drug screenings (UDS) are used as supportive materials for diagnosis and follow up stages of substance use disorders.
UDS are based on immunoassay techniques and enable a qualitative and non-quantitative analysis with detectionbased on designated thresholds. Urine drug screens in literature and Turkey are generally given in positivenegative manner so levels of extracts of substance in urine is not well known yet. It is essential to ensure their proposition of qualitative determination, in order to be able to interpret their significance. In addition, their limits need to be recognized to guarantee pertinent interpretation. $^{7}$ Whatever the method, caution is recommended for managers of clinical laboratories and good quality information is, therefore, required for clinicians in the field. ${ }^{8}$ 
In 2005, with the changes made to the Turkish Penal Code, substance abusers were no longer seen as criminals but rather as individuals in need of treatment. According to the program, carried out by the Ministry of Justice Penal and Detention Facilities Probation Directorate, the alternative of being treated was presented to substance abusers since 2006. In this way, individuals using substances would be able to be monitored in society and complete their treatment without being incarcerated. In Turkey, to purchase, accept, or possess sedative or stimulant drugs for the purpose of use is still a criminal act; however, the person using these drugs is sentenced with treatment and probation. If that person does not comply with the terms and requirements of the treatment and probation precautions, he or she is sentenced to 1 to 2 years of imprisonment. ${ }^{9,10}$ Persons that are suspected to have use of illegal drugs are directed to psychiatry outpatient clinics by forensic units and they are evaluated about substance use with UDS tests as well as psychiatric examination.

In urine drug screenings, laboratories try to obtain the most accurate result due to its legal obligations and in order to conduct the diagnosis and treatment processes properly. However, new drugs are added to addictive substances day by day. The newly added and the most common drug is synthetic cannabinoid (SC) nowadays and its screening started in Sakarya University Training and Research Hospital (STRH) laboratory in October 2014. SCs are psychoactive substances which show agonistic effects via cannabinoid receptors and have similar effects of the active metabolite of cannabis, $\Delta 9$ tetrahydrocannabinol (THC). ${ }^{11}$ More than 140 products were identified to contain SCs and such products do not only vary based on the type and amount of SCs, but also contain other psychoactive substances. ${ }^{12-18}$ So it is difficult to determine all kinds of the SC products in urine analysis.

STRH has the unique laboratory that makes drug screening in quantitative manner thus it has the quantitative laboratory records of the city. Within our knowledge, there is not any study conducted in Turkey which shows the laboratory levels of the illegal substances. Kind and urine levels of illegal substances may differ according to the profile of users including economic, cultural, genetic, phamacodynamic factors determining the profile of substance users and levels of drugs may help to find a background for future social, politic, medical, legal solutions. This study presents laboratory derived data from Sakarya about substance use during the years 2012-2015 as the first report.

\section{METHODS}

This study presents the urine analysis of all illegal substances which were made in the laboratory of STRH between March 2012 and February 2015. Illegal substance screening is conducted in our hospital mainly within the scope of Probation Services and in addition to this; drug screening is also made for diagnosis and follow-up. The results obtained from socio-demographic data and urine tests of 2948 patients were analyzed by examining their hospital record files.

\section{Evaluation of socio-demographic data}

Age and gender information of the patients screened were obtained from the database of the files according to their identity numbers.

\section{Analysis of the urine tests}

CEDIA (Cloned Enzyme Donor Immuno Assay) was used as the immunoassay method during the analysis of the urine tests. The multiplex CEDIA assay uses the genetically engineered enzyme fragments of enzyme donor (ED) and enzyme acceptor (EA) from -Dgalactoside galactohydrolase (E. C. 3.2.1.23) or 13galactosidase ( - gal) from E. coli. The generation of ED and EA, and the CEDIA homogeneous assay have been reported previously (15, U.S. Patent No. 4,708,929). The multiplex assay consists of multiple labels for the detection of amphetamine, benzodiazepine, barbiturate, opioids, MDMA (3,4-metilendioksi-N-metilamfetamin) (ecstasy), SCs, and THC drugs. In the assay, ED was covalently linked to each drug derivative in which each drug derivative is recognized by its specific antibody and the ED is capable of complementation with EA to form active [3-galactosidase enzyme. The enzyme substrate chlorophenolred-13-D-galactopyranoside (CPRG) is then cleaved by the active enzyme into galactose and CPR and CPR is measured by absorbency at wavelength $570 \mathrm{~nm}$. The antibodies bind to ED conjugates and inhibit the enzyme formation. Calibrators or samples containing amphetamine, benzodiazepine, barbiturate, opioids, and ecstasy, SCs, and THC drugs compete with the conjugates for the antibodies. The amount of free conjugates in the assay system is proportional to the concentration of amphetamine, benzodiazepine, barbiturate, opioids, ecstasy, SCs, and THC drugs in the samples or calibrator.

The drugs which could be analyzed in 2012 are THC, opioid, amphetamine, benzodiazepine, cocaine and barbiturate. Screening of ecstasy and creatine levels started from 2013 while the screening of synthetic cannabinoids started within the last quarter of 2014. The rates are given for each drug based on the sampling screened

In urine drug analysis, any drug can be subjected to measurement and the measured values exceeding certain values are regarded as positive. The measurements above those values are included in the analysis based on their cut-off values.

We used the cut off levels in workplace drug testing are recognized values for groups of drugs to determine whether a sample is positive or negative for a group of 
drugs. For the primary screen the cut off is for a group of drugs such as opioids, whereas confirmation testing is for a specific drug e.g. 6 acetyl morphine. Any result below the cut off is reported as negative, and results above the cut off are reported as either Non-negative (for screening tests) or Positive (for confirmed positive results).

The purpose of the screening test is to eliminate all negative samples quickly while highlighting samples that require further investigation. Screening test cut off levels are set at a point where there is a demonstrably high statistical probability that the drug will be detected if present. Results that fall below this are recorded as negative even though a more sensitive method would show the presence of the drug.

In order to quickly identify negative samples, screening tests are designed to react to any drug related to the target drug e.g. the amphetamine test will react to amphetamine and MDMA (ecstasy). It may also react with similar prescription or over the counter medicines. These results must therefore be confirmed by a method that can tell the difference between the different drugs within the group.

Cut off levels are; Cannabis $50 \mathrm{ng} / \mathrm{ml}$, cocaine $300 \mathrm{ng} / \mathrm{ml}$, opioid $300 \mathrm{ng} / \mathrm{ml}$, amphetamine $500 \mathrm{ng} / \mathrm{ml}$, benzodiazepine $200 \mathrm{ng} / \mathrm{ml}$, barbiturate $200 \mathrm{ng} / \mathrm{ml}$, buprenorphine $5 \mathrm{ng} / \mathrm{ml}$, respectively.

\section{Statistical analysis}

SPSS 20.0 program was used for the statistical analysis. Student's $t$-test and Mann-Whitney U test were used to compare the linear variables whereas chi square test was used to compare the cluster variables.

\section{RESULTS}

This study presents the urine analysis of all illegal substances which were made in the laboratory of STRH between March 2012 and February 2015.

\section{General evaluation of the data}

Two thousand eight hundred and fifty two (2852) $96.74 \%$ of 2948 people subjected to substance analysis are males, their ages vary between 12 and 76 and their mean age is $28.30 \pm 9.46$.

Changing based on the years in this study, positivity was determined in $34.73 \%$ of all patients subjected to urine analysis in our laboratory $(n=1024 / 2948)$, their ages vary between 14 and 70 and their mean age is $29.39 \pm 9.65$. One thousand and five $(n=1005) 98.1 \%$ of the patients determined to have substance positivity are males.

Table 1: General evaluation of 3 year data (n: 2948 people, 2169 positive urine results).

\begin{tabular}{|lllll|}
\hline Substance & \multicolumn{2}{l}{$\begin{array}{l}\text { Positive urine } \\
\text { examination (person) }\end{array}$} & $\begin{array}{l}\text { Number of positive } \\
\text { examination (urine) }\end{array}$ & $\begin{array}{l}\text { Mean urine level } \\
\text { Mean } \pm \text { SD, range }\end{array}$ \\
\hline & $\mathrm{n}$ & $\%$ & 2186 & $138.78 \pm 87.85(50-1500)$ \\
\hline Marijuana & 814 & 79.49 & 114 & $2494.03 \pm 1567(301-7552)$ \\
\hline Opioid & 54 & 5.2 & 442 & $3601.67 \pm 1958.93(500-10000)$ \\
\hline Amphetamine & 309 & 30.17 & 232 & $1931.94 \pm 1212.59(201-5000)$ \\
\hline Benzodiazepine & 94 & 9.1 & 30 & $2264.07 \pm 1383.96(311-5000)$ \\
\hline Cocaine* & 14 & 1.67 & 315 & $1478 \pm 826.60(501.17-4124)$ \\
\hline Ecstasy* & 199 & 23.74 & & \\
\hline Multiple substance** & 308 & 29.9 & & \\
\hline Total & 1024 & 100 & & \\
\hline
\end{tabular}

* Data of 2013 and 2014. ** Since screening of synthetic cannabinoid 6 acetyl morphine started later, it was not included in this table.

Table 2: Socio-demographic data of the people (n: 186) who had substance positivity in urine tests $(\mathrm{n}=596)$ in 2012 and their characteristics with regard to substance use.

\begin{tabular}{|c|c|c|c|c|c|c|}
\hline & \multicolumn{2}{|c|}{ Positive urine test person } & \multicolumn{2}{|l|}{ Age } & \multicolumn{2}{|l|}{ Gender } \\
\hline Substance & $\mathbf{N} \%$ & & Mean \pm SS, M & Max & $\mathbf{N} \%$ & \\
\hline Marijuana & 151 & 81.1 & $31.27 \pm 10.72$ & $16-70$ & $\begin{array}{l}147 \text { Men } \\
4 \text { Women }\end{array}$ & $\begin{array}{l}97.40 \\
2.60\end{array}$ \\
\hline Opioid & 6 & 3.22 & $32.83 \pm 8.49$ & $22-44$ & 6 Men & 100 \\
\hline Amphetamine & 63 & 33.8 & $28.71 \pm 8.40$ & $18-54$ & $\begin{array}{l}62 \text { Men } \\
1 \text { Woman }\end{array}$ & $\begin{array}{l}98.41 \\
1.59\end{array}$ \\
\hline Benzodiazepine & 17 & 9.13 & $32.82 \pm 8.68$ & $20-46$ & 17 Men & 100 \\
\hline Multiple Substance & 44 & 23.6 & $31.15 \pm 10.41$ & $17-56$ & $\begin{array}{l}43 \text { Men } \\
1 \text { Woman }\end{array}$ & $\begin{array}{l}97.72 \\
2.28\end{array}$ \\
\hline Total Substance Positivity & 186 & 31.20 & $31.20 \pm 10.37$ & $16-70$ & $\begin{array}{l}182 \text { Men } \\
4 \text { Women }\end{array}$ & $\begin{array}{l}97.8 \\
2.2\end{array}$ \\
\hline
\end{tabular}


Distribution of the urine positivity of the substances contain marijuana $79,5 \% \quad(n=814)$, amphetamine $30.17 \% \quad(n=309)$, ecstasy $23.74 \% \quad(n=199)$, benzodiazepine $9,1 \%(n=94)$, SC $4.9 \%(n=12 / 243)$; opioid $5.2 \%(n=54)$, cocaine $1.67 \%(n=14)$ and multiple substance $29.9 \%(n=308)$. Information about the drug distribution is given in Table 1. The average substance levels of the patients who were determined to have substance positivity in urine are 138.78 \pm 78.85 ; $2494.03 \pm 1567$ and $3601.67 \pm 1957.93$ for marijuana, opioid and amphetamine, respectively (Table 1).

\section{Data of 2012}

UDS analyses of 596 people were made in 2012 during the evaluation of the data. Mean age of the subjects corresponds to $30.21 \pm 10.11$, the age range is $13-70$ and
$97.5 \%$ of them are males. One hundred eighty six (186) $(31.20 \%)$ of them were determined to have substance positivity while multiple substance positivity was detected in 44 of 186 people $(23.7 \%)$. Among the users of multiple substances, the number of the people who use two drugs, three drugs and four drugs simultaneously corresponded to $39(88.6 \%), 3(6.8 \%)$ and $2(4.5 \%)$, respectively. Barbiturate and cocaine could not be detected in the urine tests. The number, rate and mean age of the people determined to have substance positivity in urine are shown in Table 2.

One thousand nighty and twelve 1912 package analyses were conducted for all patients in total. The number of examinations per person was detected as 1912/596= 3.20. 514 of 1912 urine samples were found to have substance positivity and their substance-based distribution is given in Table 3 .

Table 3: Analysis of the urine samples (n: 514) determined to have any substance positivity during the urine drug screenings (n: 1912) in 2012.

\begin{tabular}{|llllll|}
\hline Substance & $\begin{array}{l}\text { Positive urine } \\
\text { N\% }\end{array}$ & $\begin{array}{l}\text { Interval of the } \\
\text { measurable values }\end{array}$ & $\begin{array}{l}\text { Number of measurable urine } \\
\text { samples (over the value) }\end{array}$ & $\begin{array}{l}\text { Corrected Substance } \\
\text { Level (Mean } \pm \text { SD) }\end{array}$ \\
\hline Marijuana & 378 & 73.5 & $50-300$ & 166 & $208.98 \pm 96.10$ \\
\hline Opioid & 12 & 0.23 & $300-2000$ & 6 & $1341.45 \pm 702.02$ \\
\hline Amphetamine & 91 & 17.7 & $500-5000$ & 49 & $3059.99 \pm 2100.32$ \\
\hline Benzodiazepine & 33 & 0.64 & $200-1000$ & 6 & $553.20 \pm 269.09$ \\
\hline
\end{tabular}

Table 4: Substance usage characteristics of the patients applying in 2013 (n: 985 ).

\begin{tabular}{|c|c|c|c|c|c|c|}
\hline & \multicolumn{2}{|c|}{ Positive urine test person } & \multicolumn{2}{|l|}{ Age } & \multicolumn{2}{|l|}{ Gender } \\
\hline Substance & $\mathbf{N} \%$ & & Mean \pm SS , $n$ & tax & $\mathbf{N} \%$ & \\
\hline Marijuana & 293 & 80.9 & $29.83 \pm 9.62$ & $14-69$ & $\begin{array}{l}286 \text { Men } \\
5 \text { Women }\end{array}$ & 97.612 .39 \\
\hline Opioid & 22 & 6.1 & $31.40 \pm 10.96$ & $21-60$ & Men & 100 \\
\hline Amphetamine & 129 & 64.4 & $28.69 \pm 9.71$ & $14-69$ & $\begin{array}{l}126 \text { Men } 3 \\
\text { Women }\end{array}$ & 97.72 .3 \\
\hline Benzodiazepine & 17 & 4.7 & $29.88 \pm 8.98$ & $16-53$ & Men & 100 \\
\hline Cocaine & 4 & 1.1 & $34.75 \pm 10.27$ & $24-47$ & Men & 100 \\
\hline Ecstasy & 74 & 20.4 & $28.31 \pm 9.47$ & $14-69$ & $\begin{array}{l}72 \text { Men } \\
2 \text { Women }\end{array}$ & 97.32 .7 \\
\hline Multiple Substance & 115 & 31.8 & $28.86 \pm 9.60$ & $15-60$ & $\begin{array}{l}111 \text { Men } \\
4 \text { Women }\end{array}$ & 963.5 \\
\hline $\begin{array}{l}\text { Total Substance } \\
\text { Positivity }\end{array}$ & 362 & 36.75 & $29.49 \pm 9.60$ & $14-69$ & $\begin{array}{l}354 \text { Men } \\
8 \text { Women }\end{array}$ & $\begin{array}{l}97.8 \\
2.2\end{array}$ \\
\hline
\end{tabular}

\section{Data of 2013}

UDS analyses of 985 people were made in 2013 during the evaluation of the data. Mean age of the subjects corresponds to $28.91 \pm 9.61$; the age range is $12-76$. Nine hundred and fifty four (954) $(96.8 \%)$ of them are males. Three hundred and sixty two (362) $(36.75 \%)$ of them were determined to have substance positivity in 2013 while multiple substance positivity was detected in 115 of 362 people $(36.75 \%)$. Among the users of multiple substances, the number of the people who use two drugs, three drugs and four drugs simultaneously corresponded to $54(47.0 \%), 55(47.8 \%)$ and $6(5.2 \%)$ respectively. The number, rate and mean age of the people determined to have substance positivity in urine are shown in Table 4. In 2013, 3324 urine analyses were conducted in total. The number of examinations per person was detected as 
3.37. One thousand two hundred and fifteen (1215) of 3324 urine samples were found to have substance positivity and their substance-based distribution is given in Table 5.

\section{Data of 2014}

UDS analyses of 1367 people were made in 2014 during the evaluation of the data. Mean age of the subjects corresponds to $27.04 \pm 9.08$, the age range is $12-64$. One thousand three hundred and seventeen (1317) (96.3\%) of them are males. Four hundred and seventy six (476) $(34.82 \%)$ of them were determined to have substance positivity while multiple substance positivity was detected in 149 of 476 people (31.3\%). Among the users of multiple substances, the number of the people who use two drugs, three drugs, four drugs and five drugs simultaneously corresponded to 69 (46.3\%), 66 (44.2\%), $10(6.7 \%)$ and $4(2.7 \%)$ respectively.

Table 5: Analysis of the positive (n=1215) results obtained from urine drug screenings (n: 3324$)$ in 2013.

\begin{tabular}{|llllll|} 
Substance & $\begin{array}{l}\text { Positive Urine } \\
\text { N \% }\end{array}$ & $\begin{array}{l}\text { Interval of the } \\
\text { Measurable } \\
\text { Values }\end{array}$ & $\begin{array}{l}\text { Number of Measurable } \\
\text { Urine Samples (over the } \\
\text { value) }\end{array}$ & $\begin{array}{l}\text { Corrected Substance } \\
\text { Level } \\
\text { (Mean } \pm \text { SD) }\end{array}$ \\
\hline Marijuana & 845 & 69.54 & $50-300$ & 156 & $157.88 \pm 84.18$ \\
\hline Opioid & 40 & 3.29 & $300-5000$ & 15 & $2692.64 \pm 1902.50$ \\
\hline Amphetamine & 184 & 15.14 & $500-5000$ & 116 & $3615.96 \pm 1890.17$ \\
\hline Benzodiazepine & 22 & 1.81 & $200-5000$ & 2 & $1826.69 \pm 1401.09$ \\
\hline Cocaine & 8 & 0.65 & $300-5000$ & 3 & $3153.78 \pm 1671.80$ \\
\hline Ecstasy & 116 & 9.54 & $500-2000$ & - & $1071,75 \pm 258,42$ \\
\hline
\end{tabular}

Table 6: Socio-demographic data of the patients (n: 1367) applying in 2014 and their characteristics with regard to substance use.

\begin{tabular}{|c|c|c|c|c|c|c|}
\hline \multirow{3}{*}{$\begin{array}{l}\text { Substance } \\
\text { Marijuana }\end{array}$} & \multicolumn{2}{|c|}{ Substance positivity } & \multirow{2}{*}{\multicolumn{2}{|c|}{ Age Mean \pm SD and n-max }} & \multirow{2}{*}{\multicolumn{2}{|c|}{ Gender }} \\
\hline & \multirow{2}{*}{$\begin{array}{l}\mathrm{N} \\
370\end{array}$} & \multirow{2}{*}{$\begin{array}{l}\% \\
77.70\end{array}$} & & & & \\
\hline & & & $28,12 \pm 8,67$ & $(15-67)$ & $\begin{array}{l}364 \text { Men } \\
6 \text { Women }\end{array}$ & $\begin{array}{l}\% 98.4 \\
\% 1.6\end{array}$ \\
\hline Opioid & 26 & 5.50 & $31.50 \pm 9.18$ & $(16-63)$ & All Men & \\
\hline Amphetamine & 117 & 24.06 & $26.80 \pm 7.13$ & $(15-49)$ & $\begin{array}{l}115 \text { Men } \\
2 \text { Women }\end{array}$ & $\begin{array}{l}\% 98.3 \\
\% 1.7\end{array}$ \\
\hline Benzodiazepine & 60 & 12.60 & $33.48 \pm 11.74$ & $(16-62)$ & $\begin{array}{l}57 \text { Men } \\
3 \text { Women }\end{array}$ & $\begin{array}{l}\% 95.0 \\
\% 5.0\end{array}$ \\
\hline Cocaine & 10 & 2.1 & $38.70 \pm 9.10$ & $(25-52)$ & All Men & \\
\hline Ecstasy & 125 & 26.30 & $26.78 \pm 7.48$ & $(15-49)$ & $\begin{array}{l}12 \text { Men } \\
2 \text { Women }\end{array}$ & $\begin{array}{l}\% 98.4 \\
\% 1.6\end{array}$ \\
\hline Synthetic cannabinoid* & 12 & 4.9 & $25.83 \pm 3.63$ & $(21-33)$ & $\begin{array}{l}11 \text { Men } \\
1 \text { Women }\end{array}$ & $\begin{array}{l}\% 91.7 \\
\% 8.3\end{array}$ \\
\hline 6 acetyl morphine $*$ & 3 & 1.2 & $35.66 \pm 4.04$ & $(31-38)$ & All Men & \\
\hline Multiple Substance & 149 & 31.30 & $27.17 \pm 7.64$ & $(15-56)$ & $\begin{array}{l}147 \text { Men } \\
2 \text { Women }\end{array}$ & $\begin{array}{l}\% 98.7 \\
\% 1.3\end{array}$ \\
\hline Total Substance Positivity & 476 & 34.82 & $28.61 \pm 9.32$ & $(15-67)$ & $\begin{array}{l}469 \text { Men } \\
7 \text { Women }\end{array}$ & $\begin{array}{l}\% 98.5 \\
\% 1.5\end{array}$ \\
\hline
\end{tabular}

*This data belongs to the last quarter of 2014 and gives the rate of 243 people determined to have positivity after screening. Screening was conducted.

Table 7: Analysis of the urine samples $(n=1195)$ of the patients determined to have substance positivity.

\begin{tabular}{|llllll|}
\hline Substance & Threshold value & $\mathbf{n}$ & Cut off/above upper limit & CPSL* Mean \pm SD & CPSL*Interval \\
\hline Marijuana & 50 & 963 & none & $93.06 \pm 37.67$ & $(51-412)$ \\
\hline Opioid & 300 & 62 & 4 & $2589.01 \pm 1360.06$ & $(425-5000)$ \\
\hline Amphetamine & 500 & 167 & 118 & $3881,09 \pm 1903,84$ & $(509-5000)$ \\
\hline Benzodiazepine & 200 & 177 & 110 & $2202,08 \pm 1118,61$ & $(203-3000)$ \\
\hline Cocaine & 300 & 22 & 11 & $1940,54 \pm 1141,11$ & $(311-3000)$ \\
\hline Ecstasy & 500 & 199 & 155 & $1714,80 \pm 944,32$ & $(549-3000)$ \\
\hline SC** & 20 & 22 & none & $31,03 \pm 5,08$ & $(22,24-41,73)$ \\
\hline
\end{tabular}

After the urine drug screenings in $2014(\mathrm{n}=5201)$; *Corrected positive substance levels ** Synthetic Cannabinoid $(\mathrm{n}=1715)$ 
It was found that at most 5 drugs are used simultaneously. The number, rate and mean age of the people determined to have substance positivity in urine are shown in Table 6.

In 2014, 5201 urine analyses were conducted in total. The number of examinations per person was detected as 3.80 . 1195 of 5201 urine samples were found to have substance positivity and their substance-based distribution is given in Table 7.

\section{Comparison between the groups according to years}

The rates of determining substance positivity were compared according to years among the subjects of drug screening. $31.20 \%, 36.75 \%$ and $34.82 \%$ of the people who applied in 2012, 2013 and 2014, respectively had substance positivity. When the groups are compared through chi square test, the difference between the groups was significant (chi square $\mathrm{p}=0.000$ ) and the rate of the drug users was significantly high in 2013. $38.94 \%$ $(243 / 624)$ and $31.35 \%(233 / 743)$ of the people who were subjected to UDSin the last quarter of 2014 and within the first 9 months of 2014, respectively had substance positivity $(\mathrm{p}>0.05)$. The number of the people using the detected drug and distribution of the positive urine analyses according to years are given in Table 8 .

Table 8: Distribution of the data obtained from urine analyses according to years.

\begin{tabular}{|c|c|c|c|}
\hline & 2012 & 2013 & 2014 \\
\hline $\begin{array}{l}\text { Number of } \\
\text { the people } \\
\text { subjected to } \\
\text { substance } \\
\text { screening }\end{array}$ & 596 & 985 & 1367 \\
\hline $\begin{array}{l}\text { Number of } \\
\text { the } \\
\text { substance } \\
\text { users } \\
\text { identified }\end{array}$ & $\begin{array}{l}186(31.20 \\
\text { of the } \\
\text { applicants) }\end{array}$ & $\begin{array}{l}362(36.75 \\
\text { of the } \\
\text { applicants) }\end{array}$ & $\begin{array}{l}476(34.82 \\
\text { of the } \\
\text { applicants })\end{array}$ \\
\hline $\begin{array}{l}\text { Total } \\
\text { number of } \\
\text { the package } \\
\text { process }\end{array}$ & 1912 & 3324 & 5201 \\
\hline $\begin{array}{l}\text { Number of } \\
\text { the urine } \\
\text { samples } \\
\text { determined } \\
\text { to have } \\
\text { substance } \\
\text { positivity }\end{array}$ & 514 & 1215 & 1195 \\
\hline $\begin{array}{l}\text { Age group } \\
\text { (Substance } \\
\text { positivity) } \\
\text { Mean } \pm \text { SD } \\
\text { (min-max) }\end{array}$ & $\begin{array}{l}31.20 \pm 10.37 \\
(16-70)\end{array}$ & $\begin{array}{l}29.49 \pm 9.60 \\
(14-69)\end{array}$ & $\begin{array}{l}28.61 \pm 9.32 \\
(15-67)\end{array}$ \\
\hline
\end{tabular}

\section{DISCUSSION}

In this study ages of substance users (positive urine test) were about 29.39 \pm 9.65 . The youngest age determined was 14 , and the oldest one is 70 . Mean age of the people subjected to UDS was determined as $28.30 \pm 9.46$ and 12 and 76 are the minimum and maximum ages, respectively. This results is similar to other studies conducted in Turkey. ${ }^{19,20}$ However, the information could not be matched with the toxicological analyses in those studies. In another study conducted in Turkey, the mean age of the people subjected to substance analysis was reported as $33 \pm 11.6(18-69) .^{21}$

This study presents males for the huge amount of substance use positive urine test with the ranges over $98.1 \%$ for all substances. $96.74 \%$ of the people subjected to urine substance analysis are males. This rate corresponded to $98.5 \%, 99.5 \%$ and $95.7 \%$ in the studies in Turkey respectively. ${ }^{19,22,23}$ In the addiction unit of Ege University, the rate of males was found as $98.2 \%$ which is similar to our results. ${ }^{21}$ Although the substance use disorders increase in women in the world, they are seen more commonly in men. ${ }^{24}$ But it is thought that higher rates of men in these studies arise from mainly the probation cases.

Although the rates vary according to years, the mean rate of substance positivity was detected as $34.73 \%$ and marijuana was found in $79.5 \%$ of the subjects having substance positivity. The other substances found included amphetamine $30.17 \%$, ecstasy $23.74 \%$, benzodiazepine $9.1 \%$, SC $4.9 \%$; opioid $5.2 \%$ and cocaine $1.67 \%$ whereas the rate of multiple substances was determined as $29.9 \%$. In urine analyses of 116 people conducted in Ege University, $56(48.2 \%)$ people were found to have substance positivity and the use of marijuana, cocaine, amphetamine, opioid and multiple substance corresponded to $50(89.2 \%), 2(3.5 \%), 2$ (3.5\%), 1 (1.7 $\%)$ and $1(\% 1.7)$, respectively. ${ }^{21}$ The drugs seized by urine test in a one $\operatorname{study}(\mathrm{n}=115)$ in Turkey for substance abusers among the probationers were marijuana in 98 $(85.2 \%)$ cases, heroin in $3(2.6 \%)$ cases, ecstasy in 10 $(8.7 \%)$ cases, and cocaine in $4(3.5 \%)$ cases. $^{25}$ The studies conducted in Turkey are generally based on self-reports and UDS has become widespread due to probation cases. In one study from Turkey which published its all toxicological analyses before, marijuana was found to be the most frequently used substance after 201 cases (47.2\%) who were chosen among 425 cases and sent due to substance addiction were evaluated. ${ }^{19}$ Since the people detected to have positivity in urine tests are included in the addiction program as required by the regulations of probation, it can be considered that substance positivity was detected in 201 cases, but their toxicological analyses were not published in the relevant article. ${ }^{26}$ These findings are higher than the rates of substance positivity found in this study and similarly, the most common used substance is marijuana. In the same study, results of the urine analyses of 47 patients sent to forensic 
medicine institute show that only 13 patients and 1 patients used marijuana and amphetamine - marijuana, respectively. ${ }^{19}$ In another study which was conducted in Eastern Black Sea region based on the probation cases, 196 cases were detected to use mostly marijuana and only $10 \%$ of them had substance positivity, because the cases included mainly the first applicants and the addictive patients were sent to Alcohol-Drug research, treatment and training center. ${ }^{20}$ Results of this study are compatible with the publications and probation data showing that the most commonly used illegal substance is marijuana in our country and the world. ${ }^{27-29}$ However, most of the multiple substance use was not specified in the study, its rate found in another study is quite lower than the rate in our study (1.7\%-29.9\%) and the number of the subjects in other studies is lower than the relevant number in our study, so it causes us to think that multiple substance use is more common in essence and goes unnoticed. ${ }^{30}$

It is investigated that how many of the admissions to psychiatry outpatient clinics has substance positive urine results and how it changes year by year. Results of this study determined that the most positive proportion in urine screening test for use of illegal drugs belongs to year 2013. In 2013, 36.75 \% of persons who admitted for UDS had positive results. And it was also over $31 \%$ in 2012 and $34 \% 2014$ too.

In this study, lower substance use in 2014 compared to the data of 2013 may cause an optimist estimation asserting that the rates of substance use are decreasing. However, it is also possible that some of the substances used may be the drugs which cannot be detected in urine. $\mathrm{SC}$ is the most known substance among them. SC is a substance which the users in Turkey have started to find and use recently. ${ }^{31,32}$ In fact, SC took place in the screening which was made in the last quarter of 2014 and the first month of 2015 , with a positivity of $4.9 \%$ (12/243). The substance users know which substances can be detected in the judicial screenings and it can be thought that they keep using their preferences when the alternative of using a non-detectable substance is eliminated. After the urine screening of SC started, the number of the positive urine samples increased significantly $(38.94 \%-31.35 \%)$. This data underlines the importance of renewing the analyses of the UDS based on the current substances.

In this study, the mean substance levels of the patients having substance positivity are 138.78 \pm 78.85 , $2494.03 \pm 1567$ and $3601.67 \pm 1957.93$ for marijuana, opioid and amphetamine, respectively.

Within our knowledge, it is the first study which presents a substance profile in urine with the substance levels by making quantitative analysis in the natural sampling. The data obtained from the other countries and provinces may help us to compare the urine levels of the substances. Thus, it can be possible to reach the information about the usage amounts of the substances according to regions or excretion-distribution of the individuals having different genotypes. It is anticipated that this study can trigger the pharmacoeconomic, pharmacocultural and pharmacogenetic studies in this field.

\section{CONCLUSION}

According to the study conducted in STRH laboratory, $34.73 \%$ of the patients subjected to illegal substance analyses in urine between 2012 and 2015 were found to have substance positivity. The most found substance is marijuana and multiple substance use is common. Updating the laboratory kits in order to detect new illegal substances is important.

Funding: No funding sources

Conflict of interest: None declared

Ethical approval: The study was approved by the Institutional Ethics Committee of Sakarya University and it accords with Helsinki Declaration

\section{REFERENCES}

1. Republic Of Turkey Ministry Of Interior Turkish National Police Anti-Smuggling and Organized Crime Department, National Report to the EMCDDA 2013 by the Reitox National Focal Point: Turkey New Developments, trends, Selected Issues. Available from: http://www.emcdda.europa.eu/html.cfm/index228535 EN.html.

2. Kilpatrick B, Howlett M, Sedgwick P, Ghodse AH. Drug use, self report and urinalysis. Drug and Alcohol Dependence. 2000;58:111-116.

3. Lundy A, Gottheil E, McLellan AT, Weinstein SP, Sterling RC, Serota R. Underreporting of cocaine use at posttreatment follow-up and the measurement of treatment effectiveness. Journal of Nervous and Mental Disease. 1997;185:459-62.

4. Nolan JL. Drug treatment courts and the disease paradigm. Substance use and misuse 2002;37:172350.

5. Olshaker JS, Browne B, Jerrard DA, Prendergast H, Stair TO. Medical clearance and screening of psychiatric patients in the emergency department. Academic Emergency Medicine. 1997;4:124-8.

6. Perrone J, De Roos F, Jayaraman S, Hollander JE. Drug screening versus history in detection of substance use in ED psychiatric patients. American Journal of Emergency Medicine. 2001;19:49-51.

7. Manchikanti L, Malla Y, Wargo BW, Fellows B. Comparative evaluation of the accuracy of immunoassay with liquid chromatography tandem mass spectrometry (LC/MS/MS) of urine drug testing (UDT) opioids and illicit drugs in chronic pain patients. Pain Physician. 2011;14:175-87.

8. Melanson SEF, Baskin L, Magnani B, Kwong TC, Dizon A, Wu AHB. Interpretation and utility of drug of abuse immunoassays lessons from laboratory drug 
testing surveys. Archives of Pathology and Laboratory Medicine. 2010;134:735-9.

9. Bicak V, Grieves BE. Turkish Penal Code. Seckin Publishing, Ankara, Turkey; 2007.

10. Yenisey F. Turkish Penal Procedure Code. Beta Publishing, Istanbul. Turkey; 2009;231-232.

11. Porath-Waller AJ, Beasley E, Beirness DJ. A metaanalytic review of school-based prevention for cannabis use. Health education and behavior: the official publication of the Society for Public Health Education. 2010;37:709-23.

12. Lewin AH, Seltzman HH, Carroll FI, Mascarella SW, Reddy PA. Emergence and properties of spice and bath salts: a medicinal chemistry perspective. Life sciences. 2014;97:9-19.

13. Castaneto MS, Gorelick DA, Desrosiers NA, Hartman RL, Pirard S, Huestis MA. Synthetic cannabinoids: Epidemiology, pharmacodynamics, and clinical implications. Drug Alcohol Depend. 2014;144C:12-41.

14. Gurdal F, Asirdizer M, Aker RG, Korkut S, Gocer Y, Kucukibrahimoglu EE, Ince $\mathrm{CH}$. Review of detection frequency and type of synthetic cannabinoids in herbal compounds analyzed by Istanbul Narcotic Department of the Council of Forensic Medicine, Turkey. Journal of forensic and legal medicine. 2013;20:667-72.

15. SAMHSA. Results from the 2013 National Survey on Drug Use and Health: Summary of National Findings.: NSDUH Series H-48, HHS Publication No. (SMA) 14-4863, Rockville, MD: Substance Abuse and Mental Health Services Administration (SAMHSA); 2014.

16. Henkel D. Unemployment and substance use: a review of the literature (1990-2010). Current drug abuse reviews; 2011;4:4-27.

17. Rosenbaum CD, Carreiro SP, Babu KM. Here today, gone tomorrow and back again? A review of herbal marijuana alternatives (K2, Spice), synthetic cathinones (bath salts), kratom, Salvia divinorum, methoxetamine, and piperazines. Journal of medical toxicology: official journal of the American College of Medical Toxicology. 2012;8:15-32.

18. Ogata J, Uchiyama N, Kikura-Hanajiri R, Goda Y. DNA sequence analyses of blended herbal products including synthetic cannabinoids as designer drugs. Forensic Science International. 2013;227:33-41.

19. Karadeniz H, Birincioğlu İ, Seçilmişoğlu B, Savaş H, Zazoğlu S. Evaluation of toxicological analysis results and treatment applications in cases registered for drug addiction at parole branch office of Trabzon. The Bulletin of Legal Medicine. 2009;14.

20. Bahçeci B, Helvacı Çelik F, Kandemir G, Güveli H, Polat S. Evaluation Of The Patients Applied By Probation Referring To A Training And Research Hospital In The Eastern Black Sea Region: A OneYear Retrospective Study. J For Med. 2014;28:1-9.
21. Altintoprak AE, Akgur SA, Kitapçığlu G, Yuncu Z, Coşkunol H. Retrospective Analysis of Probationers: Sociodemographic Characteristics, Individual and Familial History Addiction and Crime, and Treatment Outcomes Journal of Dependence. 2014;15:1-9.

22. Favretto D, Pascali JP, Tagliaro F. New challenges and innovation in forensic toxicology: focus on the New Psychoactive Substances. Journal of Chromatography A. 2013;1287:84-95.

23. Isıklı S, Irak M. Investigation of substance use and addiction profile in Turkey: Year of 2002, broad region research of substance use. Turkish Psychological Association. 2002;4:55-65.

24. Greenfield SF, Back SE, Lawson K, Brady KT. Substance Abuse in Women. Psychiatric Clinics of North America. 2010;33:339-55.

25. Substance Abuse and Mental Health Services Administration Center for Behavioral Health Statistics and Quality. The TEDS Report: Age of Substance Use Initiation among Treatment Admissions; 2014.

26. European Monitoring Centre for Drugs and Drug Addiction. European drug report: trends and developments. Luxembourg: Office for Official Publications of the European Communities; 2013.

27. Zorlu N, Türk H, Manavgat Aİ, Karadaş B, Gülseren Ş. Retrospective studying of sociodemographic, clinical characteristics and extent of alcohol use disorder among patients applied by probation. 2011;12.

28. Kraus L, Augustin R, Frischer M, Kümmler P, Uhl A, Wiessing L. Estimating prevalence of problem drug use at national level in countries of the European Union and Norway. Addiction. 2003;98:471-85.

29. van Ours JC, Williams J. Why parents worry: initiation into cannabis use by youth and their educational attainment. Journal of health economics. 2009;28:132-42.

30. Bangert-Drowns RL. The effects of school-based substance abuse education--meta-analysis. Journal of drug education. 1988;18:243-64.

31. Artuc S, Doğan KH, Demirci S. Uyuşturucu maddelerde yeni trend. Sentetik kannabinoidler [New trend in narcotic drugs: synthetic cannabinoids] The Bulletin of Legal Medicine. 2014;19:198-203.

32. Bulut M, Savaş HA, Cansel N, Selek S, Kap Ö, Yumru M, Virit O. Sociodemografic characteristics of patients, applied to Substance Usage Disorders Unit of Gaziantep University. J Depend. 2006;7:6570.

Cite this article as: Tanyeri $\mathrm{P}$, Yazici $\mathrm{AB}$, Buyukokuroglu ME, Yazici E, Erol A. Urinary extract profiles of illegal substances at psychiatry and dependency clinics: three years report. Int J Basic Clin Pharmacol 2017;6:495-502. 